\begin{tabular}{|c|c|c|c|c|c|}
\hline JRL & Vol. 12 & No. 1 & Hal : 71 - 81 & $\begin{array}{c}\text { Jakarta, } \\
\text { Juni 2019 }\end{array}$ & $\begin{array}{c}\text { p-ISSN }: 2085.38616 \\
\text { e-ISSN : 2580-0442 }\end{array}$ \\
\hline
\end{tabular}

\title{
SURVEI LAUT DALAM RANGKA MENGURANGI RESIKO HAMBATAN DALAM PENGGELARAN KABEL ELEKOMUNIKASI BAWAH LAUT DI SELAT KARIMATA
}

\author{
Djunaedi Muljawan, Yudo Haryadi, Sri Ardhyastuti, Rahadian, \\ AgusSudaryanto, M.llyas, Adi Slamet Riyadi \\ Balai Teknologi Survei Kelautan, (BPPT) Jl. M.H.Thamrin No. 8 Jakarta 10340 \\ Email : djunaedi.muljawan@bppt.go.id atau muljawand@yahoo.co.id
}

\begin{abstract}
ABSTRAK
Kajian ini dilaksanakan dalam rangka rencana penggelaran kabel telekomunikasi (PT. Moratelindo) antara Pulau Kalimantan dengan Pulau Belitung. Untuk menghubungkan kedua pulau tersebut kabel akan melalui Selat Karimata. Usulan jalur kabel atau rute kabel ditentukan melalui Desk Top Study yang dilaksanakan oleh Balai Teknologi Survei Kelautan-BPPT dengan memanfaatkan informasi dan data sekunder sebagai usulan awal jalur survei. Ada beberapa potensi resiko yang bisa mengakibatkan hambatan dan kerugian pada saat penggelaran kabel, yang mana hal ini tidak bisa diidentifikasi dari data sekunder. Untuk itu perlu dilakukan survei laut, kajian dan analisis hasil survei untuk mengurangi resiko tersebut. Metoda survei laut yang diterapkan dalam kajian ini meliputi survei hidrografi, survei geofisika dangkal, dan pengambilan contoh sedimen. Hasil survei menunjukan adanya beberapa lokasi berpotensi bisa menyebabkan hambatan dalam pelaksanaan pengeelaran kabel yang disebabkan adanya objek objek berbahaya didasar laut, kelerengan dasar laut yang tajam, penurunan permukaan dasar laut, adanya terumbu karang dan kanal. Dari analisis data dan analisis potensi resiko, hasil survei laut bukan merupakan revisi perubahan rute yang besar. Namun demikian survei laut ini sangat penting dilakukan untuk mengurangi hambatan pada saat proses penggelaran mengingat bahwa mesin penggelar kabel adalah mesin yang mahal sehingga kerugian yang diakibatkan tidak dilakukan survei laut akan jauh lebih besar apabila tidak dilakukan survei laut.
\end{abstract}

Kata kunci: Survei laut, mengurangi, resiko, hambatan, penggelaran kabel

Survei Laut Dalam... JRL. Vol. 12 No. 1, Juni - 2019: 71 - 81 


\title{
MARINE SURVEY TO MINIMIZE THE RISKS OF THE TELECOMUNICATION MARINE CALBE DEPLOYMENT AT KARIMATA STRAIT
}

\begin{abstract}
This study was carried out in the framework of telecommunication cable deployment plan (PT. Moratelindo) between Kalimantan Island and Belitung Island. To connect the two islands the cable will go through the Karimata Strait. Proposed cable lines or cable routes are determined through the Desk Top Study (DTS) carried out by the Marine Survey Technology Center - BPPT by utilizing secondary data and information as the initial proposal for the survey path. There are several potential risks that can lead to obstacles and losses during cable deployment, which cannot be identified from secondary data. For this reason, it is necessary to do sea survey, study and analysis of survey results to reduce these risks. The sea survey method applied in this study includes hydrographic survey, shallow geophysical survey, and sediment sampling. The survey results show that there are several potential locations that can cause obstacles in the implementation of wiring caused by the presence of dangerous object objects at the bottom of the sea, sharp slopes of the seafloor, decreased sea floor surface, presence of coral reefs and canals. From data analysis and analysis of potential risks, marine survey results are not a major revision of route changes. However, this sea survey is very important to do to reduce obstacles during the deployment process considering that cable laying machines are expensive machines so that the losses caused by not carrying out sea surveys will be much greater if no marine surveys are conducted.
\end{abstract}

Keywords: Marine survey, reduce, risk, obstacles, deploy cable, 


\section{PENDAHULUAN}

Dalam era digitalissasi kebutuhan pembangunan sarana komunikasi menjadi prioritas Pemerintah Indonesia. Kebutuhan masyarakat terhadap layanan komunikasi dan informasi yang cepat semakin meningkat sehingga diperlukan suatu sistem komunikasi yang dapat mengatasi peningkatan kebutuhan ini. (Adinda Maulida,2018). Tantangan terbesar Indonesia dalam pembangunan teknologi informasi disebabkan oleh wilayah Indonesia yang berbentuk kepulauan. Data BPS menunjukan Indeks Pembangunan Teknologi Informasi Komunikasi IP-TIK Indonesia memperlihatkan bahwa pembangunan teknologi informasi Indonesia masih tergolong tertinggal di tingkat Asia Tenggara (ASEAN). Indonesia mendapatkan nilai sebesar 4,33 (dari skala (0-10) dan menduduki peringkat 111 dari 176 negara. Di Asia peringkat Indonesia sangat jauh berada di bawah Singapura yang berada di peringkat 18 dunia dengan nilai IP-TIK sebesar 8,05. Sementara itu, Brunei Darussalam dan Malaysia masingmasing berada di posisi 53 dengan nilai IP- TIK 6,75 dan posisi 63 dengan IP-TIK 6,38 . Hanya ada tiga negara yang berada di bawah Indonesia, yakni Timor Leste, Myanmar dan Kamboja. (Damianus Andreas, 2017).

Sebagai upaya Pemerintah Republik Indonesia dalam menjawab kebutuhan dan tantangan dalam bidang informasi dibangun infrastruktur informasi yang disebut Palapa Ring. Palapa Ring merupakan bangunan tol informasi dalam bentuk serat optik yang menghubungkan seluruh wilayah Indonesia. Sebagai infrastruktur tulang punggung jaringan telekomunikasi broadband (pita lebar), Palapa Ring terdiri dari tiga paket, yaitu alapa Ring Paket Barat, Palapa Ring Paket Tengah, dan Palapa Ring Paket Timur. Namun demikian untuk menjangkau wilayah yang tidak terjangkau Jaringan Palapa ring dibangun infrastruktur arteri yang dihubungkan dengan jaringan Palapa Ring yang dibangun oleh perusahaan swasta yang salah satunya adalah jalur kabel telekomunikasi laut antara Pulau Kalimantan dan Pulau Belitung yang dimiliki oleh P.T. Moratelindo.

PT.

Moratelindo

melaksanakan penggelaran kabel telekomunikasi antara Pulau Kalimantan dengan Pulau Belitung. Untuk menghubungkan kedua pulau tersebut kabel akan melalui Selat Karimata. Dengan demikian Selat Karimata adalah lokasi dimana akan di gelar kabel telekomunikasi bawah laut milik P.T. Moratelindo sepanjang kurang lebih $370 \mathrm{~km}$ yang akan menghubungan sistem komunikasi melalui kabel laut dari Pulau. Kalimantan ke Pulau Belitung. Posisi tempat pendaratan kabel di Pulau Belitung adalah di Tanjung Binga (sekitar Tanjung Pandan), sedangkan lokasi pendaratan kabel di Pulau Kalimantan adalah di Sungai Kakap dipinggiran Kota Pontianak.

Dalam melaksanakan penggelaran kabel dilaut terdapat permasalahan yaitu tidak diketahuinya kondisi dasar laut sehingga bisa menimbulkan berbagai resiko pada saat penggelaran kabel laut. Pada studi ini dikaji potensi resiko dan di lakukan survei untuk mengurangi resiko tersebut.

\section{TUJUAN}

Tujuan adalah untuk menentukan rute yang aman dan ekonomis untuk sistem kabel bawah laut berdasarkan penentuan kedalaman air, bahaya dasar laut dan geomorfologi

\section{METODOLOGI SURVEI}

Sebelum melakukan penggelaran kabel pada umunya dibuat Desk Top Study (DTS) untuk menentukan ususlan awal rute jalur kabel berdasarkan data sekunder berupa peta batimetri skala 
kecil dan informasi laiinya. Namun demikian informasi yang diperoleh dari DTS belum menunjukan detail terkait resiko yang ada pada rencana jalr tersebut. Beberapa potensi resiko yang bisa mengakibatkan hambatan dan kerugian pada saat penggelaran kabel, yang mana hal ini tidak bisa diidentifikasi dari data sekunder. Potensi hambatan selama proses penggelaran kabel bisa diakibatkan adanya objek objek berbahaya di dasar laut, kelerengan dasar laut yang tajam, penurunan permukaan dasar laut, adanya terumbu karang, adanya kanal, adanya singkapan batuan yang tinggi, dan lain lain.

Adapun klasifikasi resiko yang bisa terjadi pada saat penggelaran bisa diklasifikasikan sebagai berikut : (Ronald Rapp,et,all,2010)

1. Beresiko rendah, artinya tidak ada resiko yang berarti utnuk peralatan penggelaran kabel yang disebabkan kondisi dasar laut. Dalam hal ini kondisi permukaan dasar laut mudah digali dan mudah dilakukan penimbunan.

2. Beresiko sedang atau moderat, artinya berpotensi resiko menyebabkan kerusakan pada peralatan penggelar kabel namun bisa diperbaiki diatas kapal penggelar selama operasi penggelaran kabel. Potensi resiko ini bisa disebabkan kondisi permukaan dasar laut jenis sedimen yang sangat lunak $(<4 \mathrm{kPa})$ yang bisa mengakibatkan sulitnya mengendalikan alat penggelar, konfigurasi dasar laut yang berupa gelombang pasir (sandwaves) >3 meter, terdapat morfologi boulder $>0.5$ meter, terdapat singkapan batuan dengan tinggi setengah kedalaman air, kontur/ kelerengan dasar laut antara 5 derajat - 12 derajat, kelerangan samping $<5$ derajat, dan kekuatan arus laut yangkonsisten antara 1-3 meter/detik.

3. Beresiko tinggi, artinya berpotensi mengakibatkan kerusakan yang parah pada peralatan penggelar kabel sehingga tidak mungkin diperbaiki di kapal penggelar. Kondisi ini bisa disebabkan batuan keras, topografi dasar laut yang kompleks kelerangan $>12$ derajat atau kelerengan kesamping >5 derajat, adanya penurunan permukaan dasar laut yang dalam yang bisa disebabkan adanya pock mark, adanya objek objek berbahaya seperti bekas kapal tenggelam (wreck), puing-puing (debris)

Untuk mengidentifikasi hal hal yang bisa berpotensi menghambat proses penggelaran kabel perlu data dan informasi primer yang bisa dilakukan dengan survei laut. Dengan demikian survei laut yang dilakukan tujuannya adalah untuk mengidentifikasi potensi hambatan pada proses penggelaran kabel dan menjadi acuan untuk menentukan rute kabel yang aman dan ekonomis untuk sistem kabel bawah laut berdasarkan penentuan kedalaman air, jenis sedimen, bahaya dasar laut dan geomorfologi. 


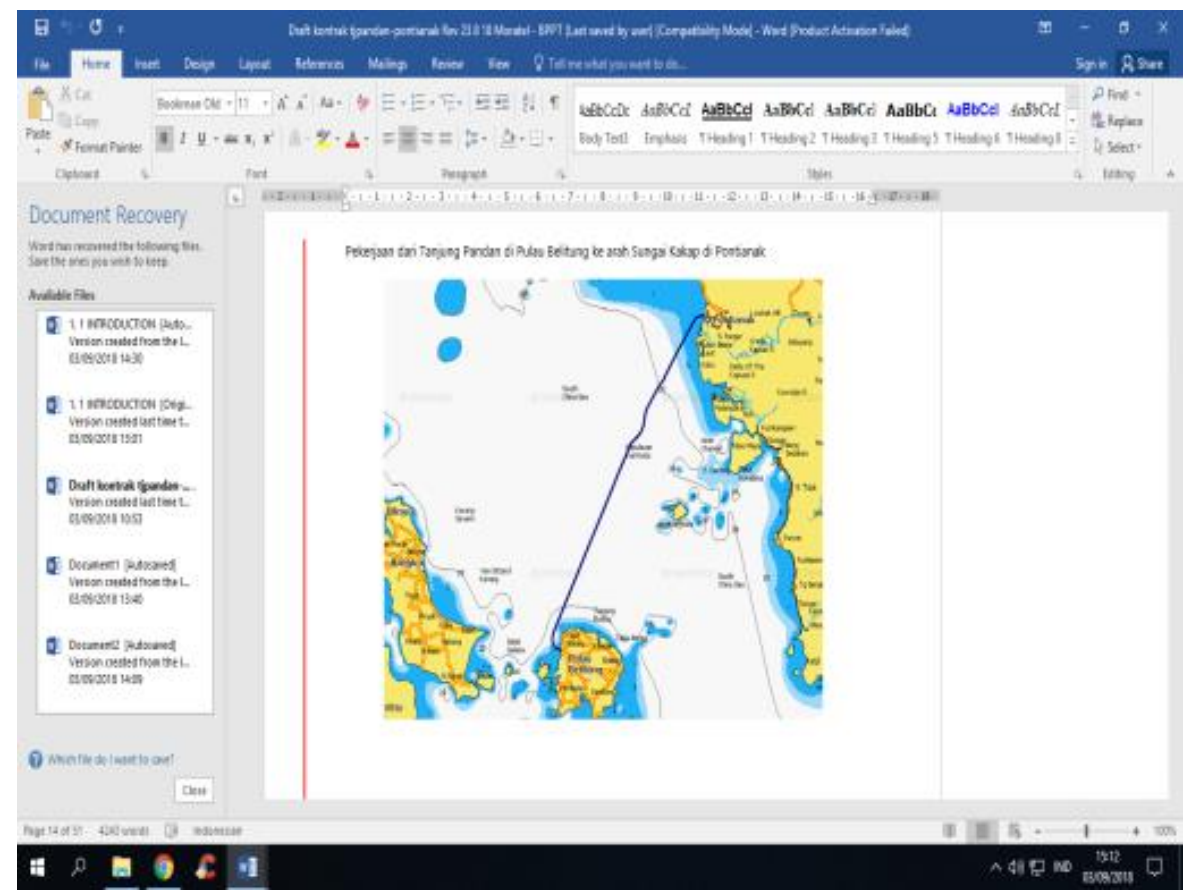

Gambar 1. Lokasi survei

Metoda yang dilakukan adalah pengambilan data dengan menggunakan wahana K/R Baruna Jaya IV. Peralatan yang dipakai diantaranya

- Survei Hidrografi dengan menggunakan peralatan Multibeam Echousounder.

- Survei Geofisika dangkal dengan menggunakan Side Scan Sonar, Sub Bottom Profile, dan Magnetometer

- Pengambilan contoh sedimen dengan menggunakan gravity core dan grab sampler

\subsection{Survei Hidrografi}

Survei hidrografi dilakukan untuk memperoleh data dan informasi kedalaman dan kelerengan permukaan dasar laut. Survei ini menggunakan wahana K/R Baruna Jaya IV dengan panjang kapal 64 meter, lebar 11.5 meter. Untuk kedalaman laut lebih dari 10 meter. Sedangkan untuk kedalaman laut kurang dari 10 meter menggunakan wahana kapal kayu local, yaitu di pantai Tanjung Binga di Pulau Belitung dan perairan Sungai Kakap di Pontianak Kalimantan Barat.

Alat pengukuran kedalaman yang digunakan di K/R Baruna Jaya IV adalah Multibeam Echosounder System (MBES) ELAC Sea Beam 1180 dengan frekuensi $180 \mathrm{kHz}$. Sistem penentuan posisi dilakukan dengan menggunakan CNAV-1000 Differential GPS. Selain itu juga dilakukan pengukuran kedalaman dengan Single Beam Echo Sounder (SBES) ELAC LAZ 4410. Untuk kalibarasi kecepatan suara digunakam pengukuran kecepatan suara dalam air CTD SBE 911. Pengukuran hidrografi di area pantai (kedalaman kurang dari 10 meter) digunakan MBES LSE 307 SSE 30 dengan frekuensi $180 \mathrm{kHz}$ dan SBES ODOM Echotrack MKIII dengan frekuensi $100 \mathrm{kHz}$. Sistem penentuan 
posisi yang digunakan adalah C-Nav DGPS

\subsection{Survei Geofisika Dangkal}

Survei geofisika dangkal dilakukan untuk memperoleh informasi dan data keberadaan objek-objek yang berada di dasar laut, strata sedimen dan morfologi dasar laut. Seperti halnya survei hidrografi, untuk kedalaman 10 meter dan lebih dalam, digunakan wahana K/R Baruna Jaya IV. Sensor yang digunakan adalah Side Scan Sonar (SSS) EdgeTech 4100HF dual frekuensi $110 \mathrm{kHZ}$ dan $410 \mathrm{kHz}$ yang ditarik di belakang burtitan kapal. Untuk mengetahui objek yang bersifat logam digunakan magnetometer Geometric G882 (akurasi $10 \mathrm{nT}$ ) yang juga ditarik di buritan kapal dengan jarak 60 meter dari kapal. Profile strata sedimen diketahui dengan menggunakan Sub Bottom Profiler (SBP) Oretech 3010 (3.5 - 14 $\mathrm{kHz}$ ) yang terpasang secara permanen di lambung K/R Baruna Jaya IV. Untuk kedalaman laut kurang dari 10 digunakan kapal kayu

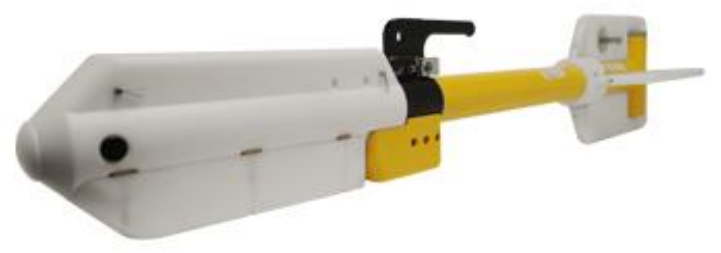

Gambar 2. Magnetometer G.882

\subsection{Pengambilan Contoh Sedimen}

Pengambilan contohh sedimen diperlukan untuk mengetahui jenis dan kekerasan sedimen. Pengambilan contoh sedimen pada kedalaman laut lebih dari 10 meter dilakukan dengan menggunakan gravity Core Kullenberg diameter 5 inch dan 3 meter panjang serta pemberat $100 \mathrm{~kg}$. Dengan menggunakan alat ini diharapkan bisa memperoleh contohh sedimen dengan ketebalan 2 meter dari permukaan dasar laut.

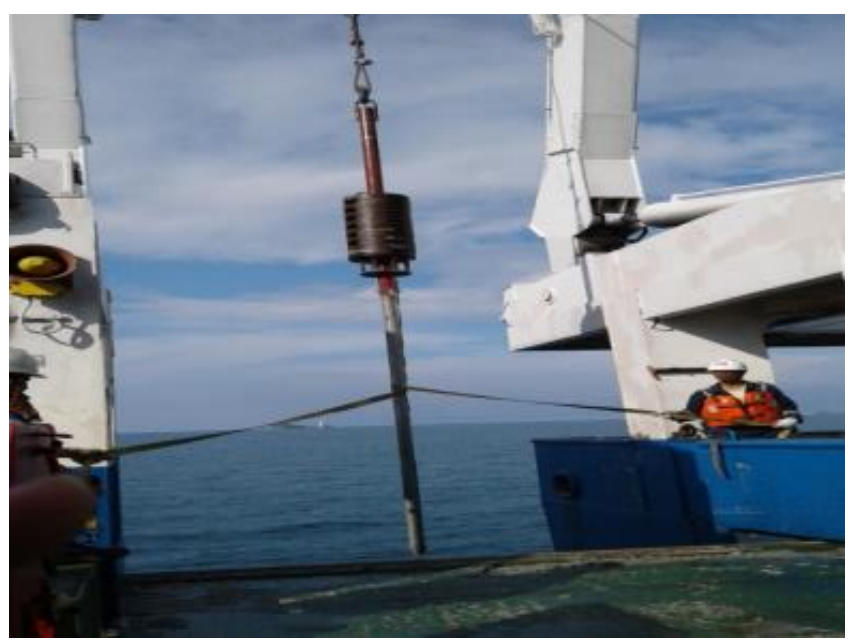

Gambar 3. Gravity Core Kullenberg 
Pengambilan contoh sedimen pada kedalaman laut kurang dari 10 meter digunakan grab sampler. Hal ini dikarenakan tidak memungkinkan penggunaan Gravity core di wahana kapal.

\section{HASIL SURVEI DAN INTERPRETASI}

Hasil yang diharapkan dari survei laut ini mampu mengidentifikasi potensi resiko di sepanjang usulan jalur kabel telekomunikasi dan merevisi usulan rute untuk meminimalisasi resiko. Dengan demikian terjadi perubahan rute namun masih dalam koridor rute usulan awal dengan lebar koridor 250 meter.

Dari hasil survei hidrografi, geofisika dangkal dan pengambilan contoh sedimen di sepanjang jalur kabel awal ada beberapa objek, gambaran permukaan dasar laut, data kedalaman dan kelerengan serta kondisi geologi yang dipertimbangkan sebagai alasan untuk merevisi rute jalur kabel untuk meminimilasi resiko pada saat proses penggelaran kabel diantaranya :

1. Terdapat cekungan yang diakibatkan penurunan permukaan. Penurunan permukaan ini menyebabkan kelerengan pada rute kabel lebih dari 12 derajat. Hal ini bisa mengakibatkan tergulingnya mesin penggelar kabel.

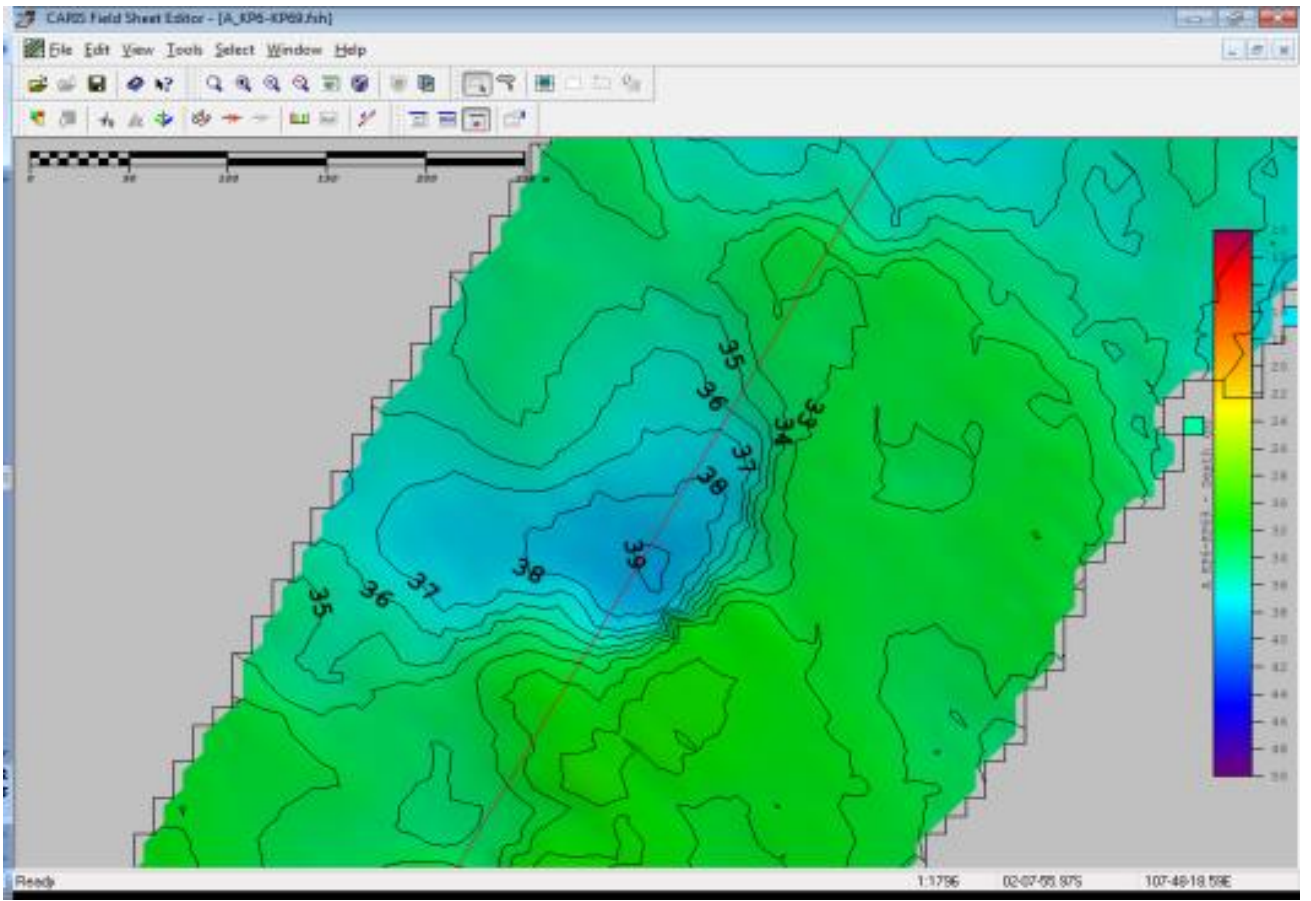

Gambar 5. Hasil interpretasi data batimatri yang menunjukan adanya cekungan dengan kedalaman sekitar 4 meter di dekat jalur kabel. 
2. Teridentifikasi keberadaan kondisi geologi yang diinterpretasikan sebagai rembesan gas. Rembesan gas dapat menyebabkan keberadaan karbonat authigenik yang diturunkan dari metana (Methane -

Derived Authigenic Carbonate$M D A C)$. Pengerasan dasar laut yang dibentuk oleh oksidasi mikroba metana dan pengurangan sulfur. dapat peralatan (Cathie, 2018)

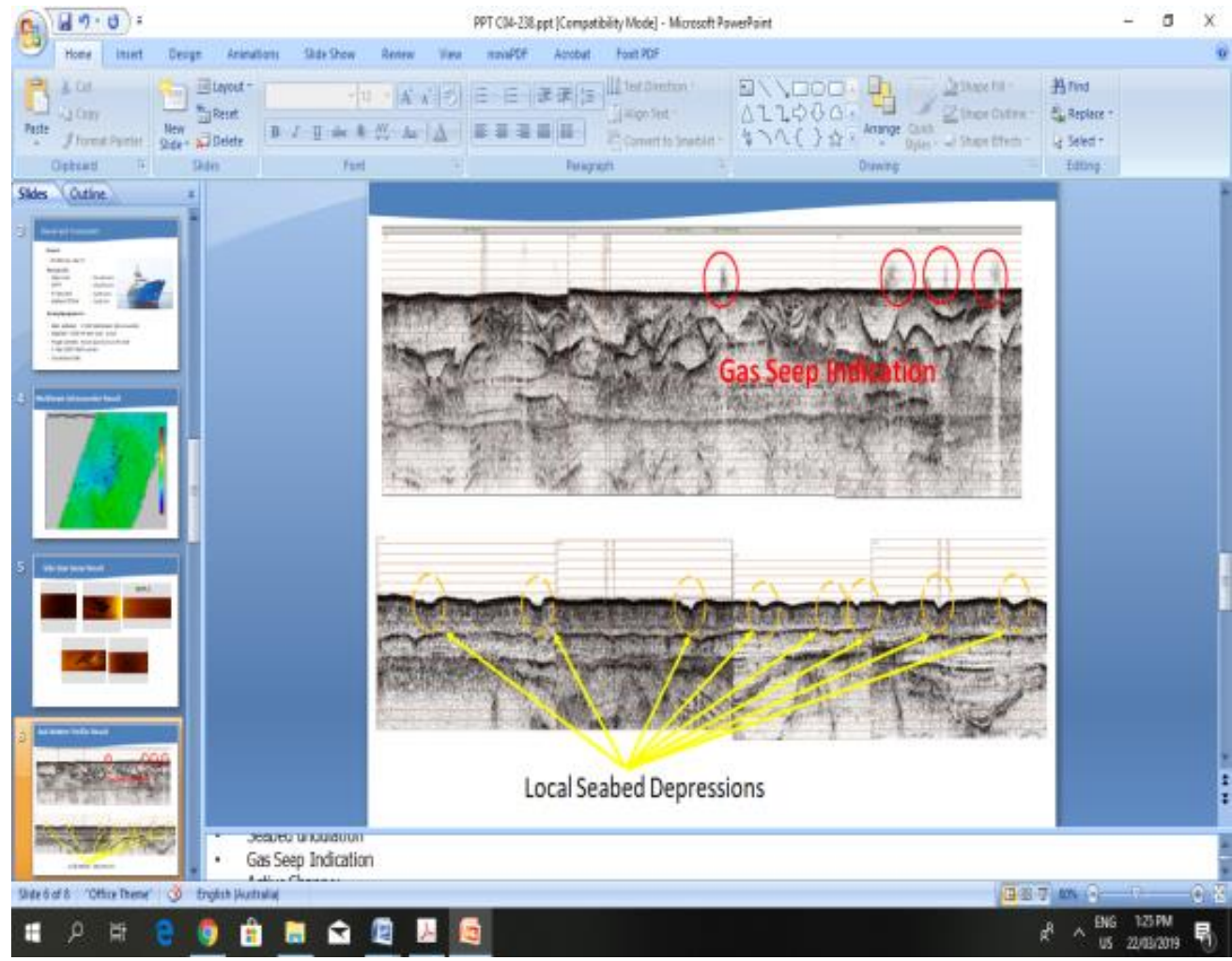

Gambar 6. Hasil interpretasi data Sub Bottom Profilling yang menunjukan adanya struktur dibawah permukaan dan kenampakan seep gas.(Yudo H,2018)

3. Dari data Side Scan Sonar teridentifikasi beberapa puing (debris), pockmark, scar, wreck, gravel. Pockmark bisa saja diakibatkan adanya rongga dibawah permukaan disebabkan gas. Untuk memperkecil resiko perlu di dilakukan pembelokan rute penggelaran kabel. Scar atau bekas garukan mengindikasikan telah terjadi aktivitas penjangkaran di lokasi terebut yang mungkin saja bisa terjadi lagi kegiatan penjangkaran di lokasi tersebut, hal membahayakan apabila kabel telah terpasang. 


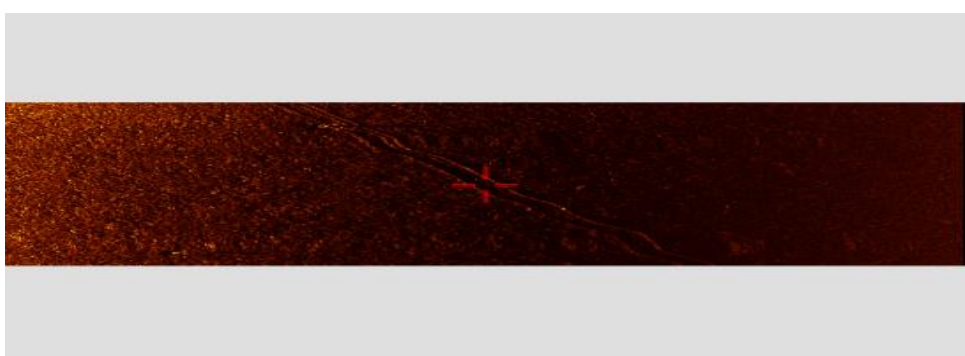

Gambar 7. Hasil interpretasi data side scan sonar yang menunjukan adanya scar atau bekas garukan yang mungkin pada lokasi ini sering terjadi aktivitas penurunan jangkar. (Yudo $\mathrm{H}, 2018$ )

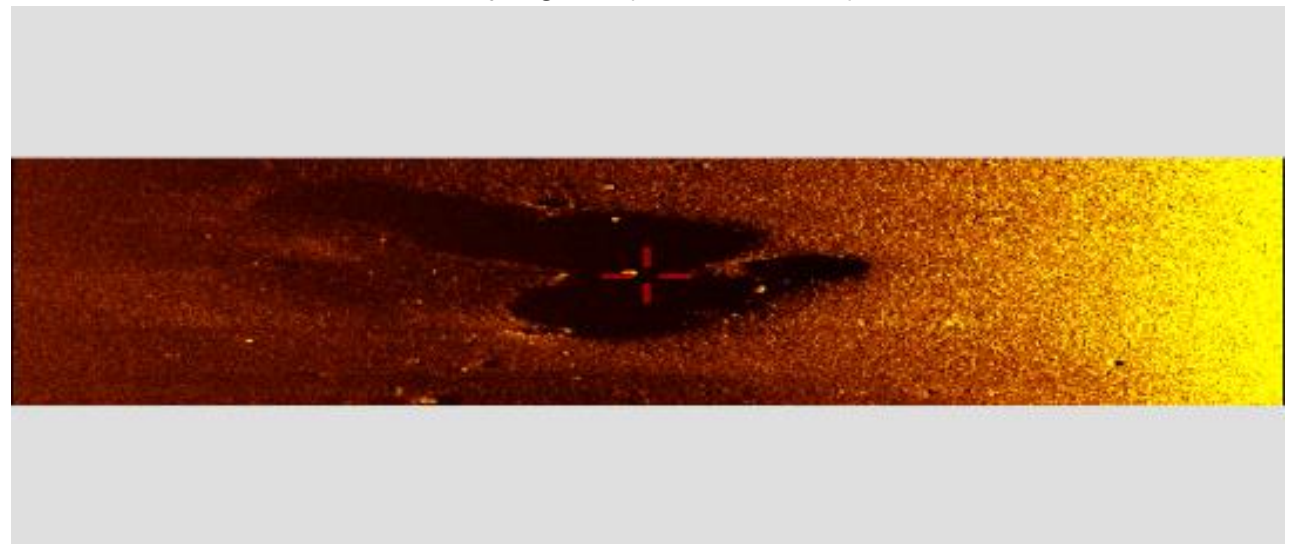

Gambar 8. Hasil interpretasi data side scan sonar yang menunjukan adanya pockmark atau penurunan permukaan dasar laut yang berbentuk lingkaran.(Yudo $\mathrm{H}$. dkk, 2018)

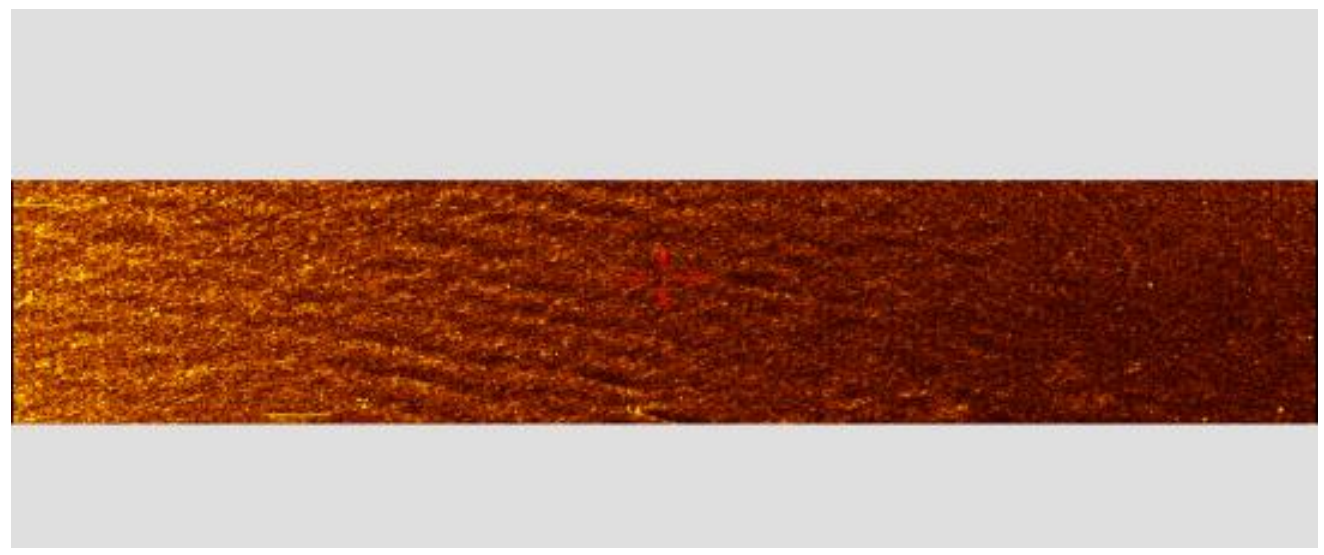

Gambar 9. Hasil interpretasi data side scan sonar yang menunjukan adanya scar atau gerukan (Yudo H. dkk, 2018) 


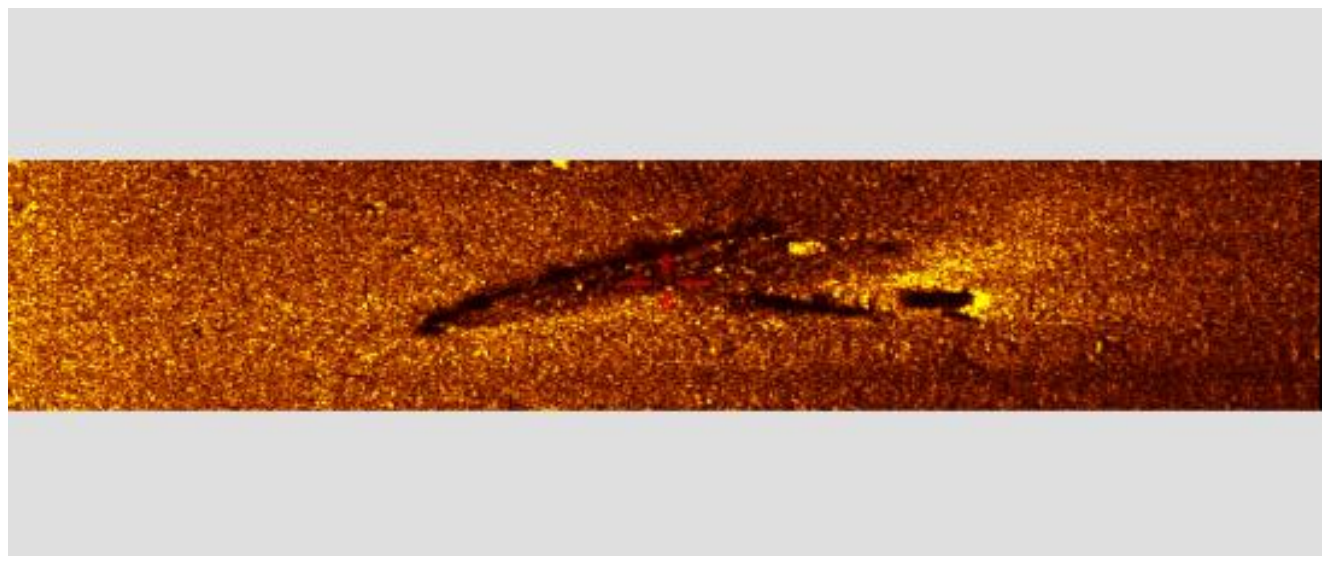

Gambar 10. Hasil interpretasi data side scan sonar yang menunjukan adanya wreck, Yudo H. dkk,2018)

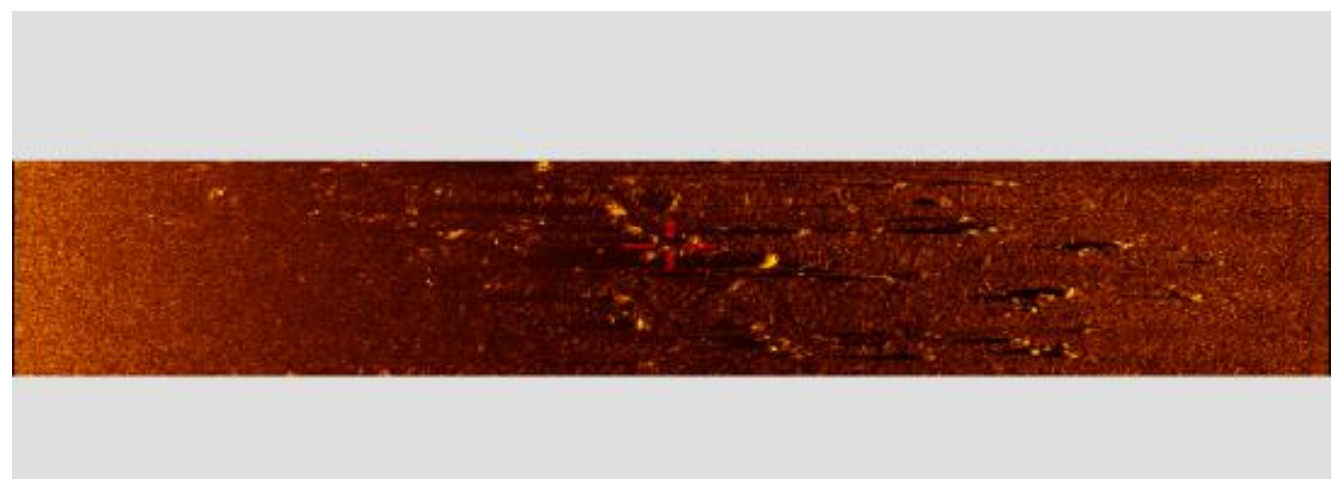

Gambar 11. Hasil interpretasi data side scan sonar yang menunjukan batuan permukaan agak kasar (gravel)

\section{KESIMPULAN}

Survei laut untuk mengidentifikasi potensi resiko pada jalur kabel yang di tentukan melalui DTS perlu di lakukan untuk memperkecil resiko hambatan pada saat proses penggelaran kabel. Namun demikian rute yang direvisi masih dalam koridor 250 meter yang ditentukan dalam DTS. Dengan demikian revisi rute dari hasil survei laut bukan merupakan revisi perubahan rute yang besar. Namun demikian survei laut ini sangat penting dilakukan untuk mengurangi hambatan pada saat proses penggelaran. Perlu diketahui bahwa mesin penggelar kabel adalah mesin yang mahal sehingga kerugian yang diakibatkan tidak dilakukan survei laut akan jauh lebih besar apabila tidak dilakukan survei laut atau hanya mengandalkan data sekunder sebagi sumber DTS.

\section{UCAPAN TERIMA KASIH}

Ucapan terima kasih yang begitu besar ditujukan pada Balai Teknologi Survei Kelautan-BPPT dan P.T Moratelindo atas dijinkannya untuk menggunakan data pada penulisan ini. 


\section{DAFTAR PUSTAKA}

Adinda Maulida, dkk, 2018, Perancangan Sistem Komunikasi Kabel Laut Sangatta-Towale, Makalah SENIATI- ISSN 20854218, ITN-Malang

Agus Sudaryanto, dkk, 2018 , Desk Top

Study Report, Moratelindo

Tanjung Pandan - Sungai Kakap SubMarine Cable System, P.T Mora Telematika Indonesia, BPPT, Jakarta

Cathie,, 2018, Cable Protection Analysis Report, Cathie Associates, Newcastle upon Tyne, UK

Damianus Andreas, 2017, BPS : Indeks

Pembangunan

Teknologi

Informasi Indonesia Masih

Rendah, Artikel, Jakarta

Djunaedi. M, dkk. 2018, Marine Survey

Final Report, Moreatelindo

Tanjung Pandan - Sungai Kakap SubMarine Cable System, P.T Mora Telematika Indonesia, BPPT, Jakarta

John M. Reynolds, 2011, An Introduction to Applied and Environmental Geophysics 2 $2^{\text {nd }}$ Edition, John Wiley \& Sons, Ltd, West Sussex.

Penrose,et all, 2005, Acoustic Techniques forSeabed

Classification, CRC Coastal Zone

Estuary and Waterway Management

Rahadian, dkk, 2018, Laporan Survei Selat Malaka 2018: Balai Teknologi Survei Kelautan, Jakarta

Ronald Rapp, Chris Carobene, Frank Cuccio, 2010, BURIAL ASSESSMENT AND SUCCESSFUL CABLE BURIAL: OLD TOPIC, NEW LESSONS,
Tyco Electronics Subsea Communications LLC (TE SubCom), Suboptic, Morristown.

Yudo Haryadi, dkk, 2018, Appendices of Marine Survey Final Report, Moratelindo Tanjung Pandan Sungai Kakap Submarine Cable System, P.T. Mora Telematika Indonesia, BPPT, Jakarta 